\title{
English Teachers' Subjectivities: Contesting and Resisting Must-be Discourses
}

\author{
Pilar Méndez ${ }^{1}$, Eliana Garzón ${ }^{2}$ \& Rodolfo Noriega-Borja ${ }^{3}$ \\ ${ }^{1}$ Science and Education Faculty, Doctoral Programme Studies in Education, Universidad Distrital Francisco \\ José de Caldas, Bogotá, Colombia \\ ${ }^{2}$ Science and Education Faculty, Undergraduate Programme in English, Universidad Distrital Francisco José de \\ Caldas, Bogotá, Colombia \\ ${ }^{3}$ Education trainer, Ministry of Education, Bogotá, Colombia \\ Correspondence: Pilar Méndez, Universidad Distrital Francisco José de Caldas, Sede Aduanilla de Paiba, Bogotá, \\ Colombia.
}

Received: November 5, 2018 Accepted: January 26, 2019 Online Published: January 29, 2019

doi: $10.5539 /$ elt.v12n3p65

URL: https://doi.org/10.5539/elt.v12n3p65

\begin{abstract}
This paper problematizes the meaning of subjectivity constructed by Colombian English Teachers in response to a National Bilingual Program and its system of reason to produce English teachers' identity and promote bilingual education. The double-side character of subjection/subjectification (Foucault, 1982) is used to analyze English teachers' work of the self and contestarian/resistance practices to affirm themselves as researchers and critical thinkers but also to claim recognition as educators who produce relevant and situated knowledge. Historical Discourse Analysis, through archeological procedures (Foucault, 1972) to trace back English teachers' discursive and non-discursive practices, were key to unveiling how teachers think of themselves as English teachers, oppose policies and respond to dominant discourses in relation to English teaching. More than 100 English teachers' academic publications were revised and confronted with normalized discourses circulating in political programs, print media and experts' documents. Findings contribute to EFL teachers' understanding of their own struggles and the role of their resistance practices to affirm their subjectivities.
\end{abstract}

Keywords: subjectivity, resistance, bilingualism, policies, archeology, discursive practices

\section{Introduction}

After 15 years of the implementation in Colombia (South America) of the National Bilingual Program much has been said about its impact in terms of success or failure. The common ground to argue either in favor or against it uses statistics reports to compare progress, economic reports to value budget investment and discursive practices intertwined with ideas of productivity and competitiveness as measures of social efficacy. Within these reports English teachers are reduced to figures to indicate their English Language Level according to the Common European Framework (A1, A2, B1, B2, C1, C2) or the numbers of teachers benefiting in training programs, but little is known about English Teachers' struggles, particularly regarding the effects of the National Bilingual Program promotion in the ways they have been constructed and perceived by society in general. One cause of this neglect derives from the normalization practices of favoring language proficiency; reifying a native-like identity and making invisible other constituent aspects of being a teacher in our country, which was repeated as dogma in the rhetoric of a reform, affecting the ways English Teachers are perceived as deficitarian subjects. In this respect, central to this study is a concern with the English Teachers' construction of their subjectivities in relation to the idealized dominant consideration of how an English teacher must be via policies and dominant discourses.

In this sense, this research views the relation of subjectivity and policies through several lenses: it shows the ways in which conceptions of language policies in relation to bilingualism served to produce a type of English Language Teacher who is a mere technician to fulfill practices of marketing; it brings to the surface power-knowledge confronting forces between dominance and resistance discourses in ELT education; and it seeks to understand the struggles of English Language teachers to contest and dismantle a system of reasoning that diminishes them and attempts to steal their conditions of possibility to think, act and be different. For doing 
so, this research revolved around these questions: How have English teachers been constituted as subjects? How do policies (NBP) influence English teachers' image construction? What do English teachers think of themselves?

Although several studies have explained the relation reform and teachers' resistance to change as a matter of fear to change (Fullan \& Hargreaves, 2013), scarce participation in the reform elaboration (Stanulis et al., 2016; Guerrero, 2009), coupled with the inability of reform to negotiate principles and ideologies (Terhart, 2013) that are important to understand how to implement a policy from above, evidence that few studies (Guerrero \& Quintero, 2016) have paid special attention to teachers' discourse and non-discourse practices to contest a policy when they already had decided upon a course of action. When we embarked on this research, we were noticeably seduced by the idea of revising the relation policy-subjectivity via National Bilingual Plan effects on it, but archeology procedures helped us to trace back an important event in the history of languages teaching in Colombia, namely the turn to English as a marketing device of citizenship, that affected the idea of learning languages as cultural devices. Situation that can also be portrayed in other international contexts where English is learnt as a foreign language (e.g. México, Chile and other Third World and Colonized countries). We have sought to show English teachers' struggles to resist this new domain of marketing and economic governance (Lazzarato, M. 2014) in relation to languages and the production of subjectivity to understand English teachers' discursive and non-discursive practices to think of themselves.

\subsection{Relevant Related Literature}

The study of subjectivity has been dominated by deterministic theories whereas dominant discourses operate as must be discourses to assign to us an identity, a sex, a profession, and a mission. Although studies of this kind have been important to understand how the production and manufacture of subjectivities have served a system of reasoning that normalizes (for example, technologies of capitalism, see Guattari, 1996, and subjective economy in Lazzarato, 2014; Western thought, see Foucault, 2011) the study of subjectivity from the perspective of resistance, it has been discarded or relegated to the background to refer to the governance of their own existence in the ELT field. To discuss here, subjectivity is seen as an empirical reality and an analytic category (Biehl, Good, \& Kleinman, 2007) in the sense it can be traced as a discursive formation in the historical and contingent processes of identities production but also it can be experienced as an interior process in which subjects struggle to disrupt imposed modes of subjectivation to assign themselves an individual subjectivity (Foucault, 1981). When considering technologies of the self, Foucault (1988) explains how individuals exercise a series of procedures to accept an identity, keep it or transform it, keeping in mind how a new understanding of a non-essential subject sheds light on the ways individuals work on themselves to shape their subjectivities. One important axis of this new understanding has to do with the heterogeneity and contingency of our subjectivities as they unfold within the realm of experience (Kleinman \& Fitz-Henry, 2007), which encompasses power-resistance practices but also negotiations, contradictions and assertions.

It is worth mentioning that the growing interest in subjectivity from different perspectives (feminist, psychoanalytic and postmodern theories) has pushed -in several fields- a type of research interested in the self-reflective activity (Atkins, 2005) of individuals to understand how these cope with day-to-day pressures and difficulties, contemporary, affected by a system of reasoning that promotes efficiency, competition and normalized identities (techniques of domination) and trying to understand how individuals exercise some actions (techniques of the self) to reach a self-governing existence in which they meet their own aspirations Although in the ELT field, the interest in identity as an analytical category has served to explore some aspects of subjectivity (Castañeda-Peña \& Ubaqué, 2017; Guerrero \& Meadows, 2015; Pennington, 2015; Cheung, 2015; Guerrero \& Quintero, 2013; Viafara, 2016; Arcila, 2007); few studies have been devoted to analyzing it as a practice of self-understanding and self-governance. In this sense, this research is a contribution to the ELT field from the line constitution of subjects, subjectivity and resistance practices to examine Colombian English Teachers' struggles in their quest for giving sense to their life and work in a context full of suspicion, criticism and public scrutiny.

\subsection{Background}

Within the framework of the National Bilingual Program, the proliferation of discourses around the Colombian English teacher image are subjected to the scrutiny of his/her role in teaching, language proficiency, preparation and need for certification. Different projects, plans and programs, among them: Strengthening of a Second Language, Sectoral Education Plan 2004-2008- Bogota a Great School, Ten-Year Education Plan 2006-2016, Education Sector Plan 2008-2012, Teach Challenge Study, 2008 -2013, National Program of Bilingualism 2004-2019, Strengthening and Development of a Program of competences in foreign languages, 2010-2014 and 
recently, the National English Plan 2015-2025 in Colombia were established as truth regimes that validated training processes' power and control over English teaching; thus revealing education as a highly productive force of institutions and processes.

By looking back at the past, we could note that there was a turn in the way of understanding the teaching of foreign languages in Colombia. In the past, the teaching of languages such as Latin, English, German and French were considered special courses for the education of high school students, which can be checked out in the Education Curricula for the periods 1930-1950. Then, from 1950-1970, languages teaching just focused on English and French; although Latin could be studied as an optional course. After 1998, French was officially removed from curricula and the "kingdom" of English as the official foreign language in official education started. English was then introduced and continues to be promoted by print media as the universal language, the language of professional success and social progress, the language of technology and sciences (Note 1). This turnabout is important to problematize the promotion of a bilingual subject (that must speak English and Spanish) with the notion of marketing of the self (Lazzarato, 2014; Macedo et al., 2003) that can be depicted as an effect of imperialism to produce for Colombian citizens a desire to work their subjectivities in direct relation to English The revision of these political and educational programs introduced English as a reason of marketing in a particular period in the history of Colombian society, where English teachers must cooperate by obeying the national policies and experts' recommendations on language competence, promoting their identity as certified teachers willing to be tested through international texts.

\section{Method}

This study is framed into Historical Discourse Analysis and based on archeological procedures to trace discursive formations. Although, there are different ways of conducting this type of research, this one in particular took into account the Foucauldian perspective in which a great number of registers are confronted with social, political, and educational discourses to understand the ways in which some regularities and discontinuities emerge as part of a governmental domain. Archeological procedures based on analytical and critical reading are demanded as part of a strategy to unveil the enunciative function of a series of signs, "a series that is not necessarily grammatical or logical structures" (Foucault, 1972, p. 108) but discursive formations. In this sense, "in the act of enunciation" as Lazzarato (2014) explain it better, "a power of self-positioning, self-production and a capacity to secrete one's own referent emerges" (p. 18) which is important to understanding subjectivity from the individual perspective. But also, discursive formations act as forces produced by different domains of knowledge in which social subjection imposes subjectivity upon us. In this type of analysis, registers were confronted and analyzed by growing polymorphism, suspended and dispersed points, causal disaggregation to produce grids of specification with the potentiality to tackle events, repetitions, discontinuities, and connections that can be depicted as polyhedron of intelligibility of a particular practice (Foucault, 1972).

\subsection{Corpus}

The Historical Analysis puts forward a relational organization of statements: "statements different in form and dispersed in time form a group if they refer to one and the same object" (Foucault, 1972, p. 32). In reviewing the history of language teaching in Colombia, we traced registers from different documentary sources, not only those confined to education itself but politics, economics, social processes, behavioral patterns, and systems of norms. The revision of around 150 articles from digital media and some printed versions of the media, also the revision of around 60 official documents from government and The British Council, as experts, and particularly more than 120 issues of academic journals to revise English teachers' pronouncements were read to regroup statements into an amalgam of themes. As part of the thematic articulation, English as the language to be learnt was cemented as a new regime of truth. News media and ads, in which statistic reports about the Colombian English Teachers' low proficiency levels were exposed and promoted the idea of "Colombian English Teachers do not speak English", thus there can be no success for the National Bilingual Program without "certified teachers". As graphic 1 shows, the number of entries in relation to English and its promotion increased over time and this cartography is key to understanding the continuum of the promotion of a practice (Appendix A) in which learning English became a must to impact citizens' subjectivity and criticism of Colombian English teachers. 

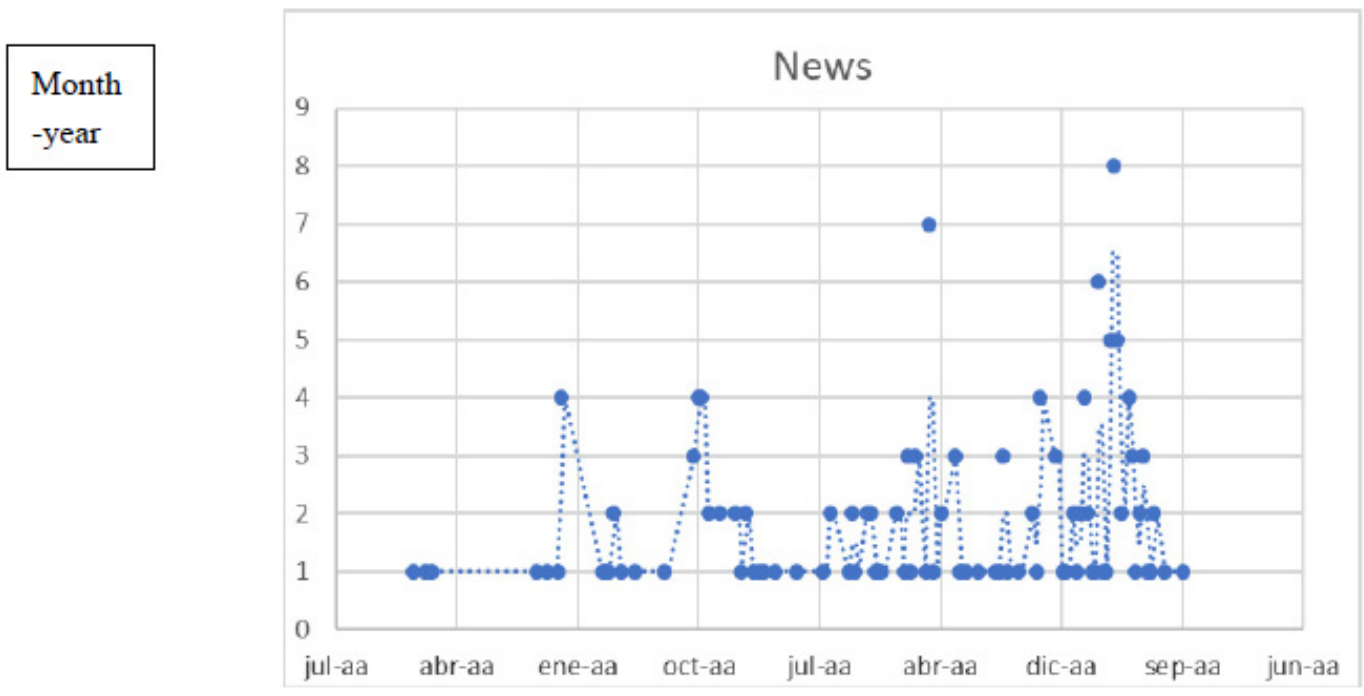

Source: 150 news revised from media press

Graphic 1. Media press cartography

On the other hand, the analysis of official documents from government and experts, shown in the Table 2 (Appendix B), allows us to revise the construction of English as the language of the official and social pact to think of bilingual education in the country. Emergent themes cast light on the ways some forces shaped the establishment of a new code of relating to English for the sake of economic profit and growth, development and competitiveness of the country. This view is reinforced by experts such as The British Council (BC), that promotes the native speaker identity-like to help the non-native English teacher "to be a more effective English teacher" (BC, 2018) and suggesting the Common European Framework to standardize English proficiency certification levels in Colombia. In this sense, we have the notion of the English Teacher as a cooperating partner of the National Bilingual Program to facilitate its promotion and success.

In turn, in the academic journals, English teachers are direct questioners of the ways English language has been promoted. More importantly, their position as authorized subjects to speak about the National Bilingual Program's contradictions and its exclusionary and unfair practices are exposed while they claim for themselves conditions of existence quite far from the system of ideas imposed by the National Program and its promoters. The referential nature of their statements gives meaning to contestarian practices that correlated a domain of other practices in direct relation or not to the policies, but crucial to understanding the ways they have perceived themselves and have constructed their subjectivities. The spatial distribution of these statements (graphic 2) is important for understanding historically correlated practices of self-governance exercised by teachers while relating to other objects (policies, English, teaching, labor, etc.). 


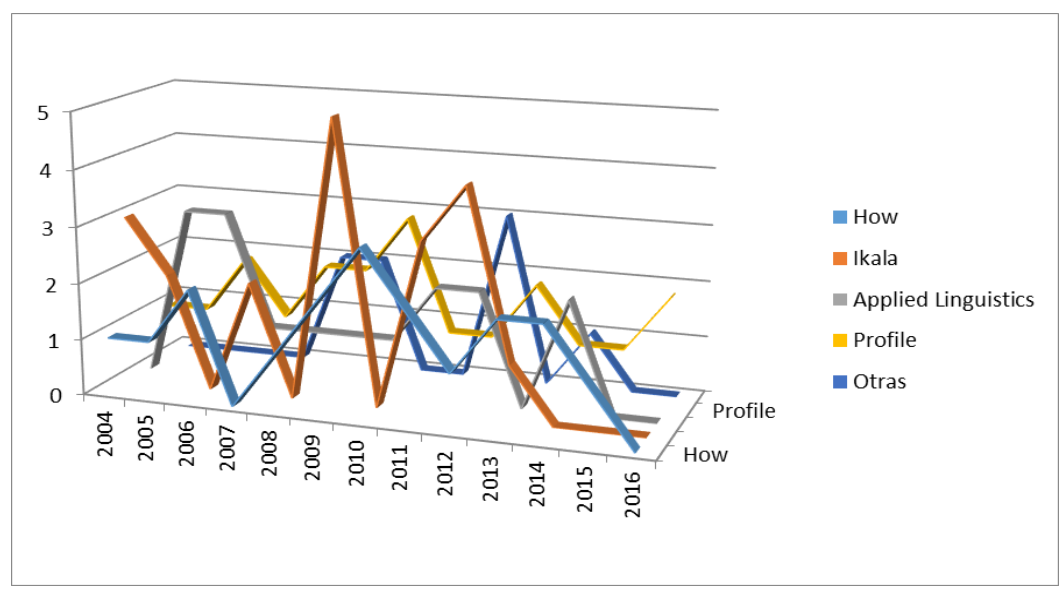

Source: academic journals from Colombia

Graphic 2. English teachers /academic journals cartography

\section{Results}

Graphics presented earlier on mapped the terrain of emerging statements in which reiteration, co-occurrence and repetition within a type of rationalization in which English was cemented as the language for bilingualism in Colombia deviated from a mode of bilingualism comprehension and rejected any other mode of relating to foreign or local languages to promote one's identity. With this idea of "only English" to promote bilingualism and the need for an English Certified Teacher proliferated in the media, in official and expert discourses, in the media that to a point acted as forces that have influenced the way of thinking about bilingualism in Colombia and the English teacher needed for the success of the program, we notice how a domination device operates to "delineate how things and people get ready, put on at disposal and what means of seeing and saying dispose in it individuals "(Schérer, R., 2005, p. 252), in order to hold the bodies, accustom them to the tenor of a practice and arrange the mechanisms to serve this instrument of subjectivity production, either through desire or response. As shown in Appendix A, the reiteration of certain types of statements in relation to English, such as: lack of "English speakers", "English as a must for work and success", "English as a business", and "nativeness as a model" served to validate a new type of statements to refer to local English teachers as "not well prepared", "unqualified" and "who do not speak English". This kind of statements relate deeply with policymaking and experts" reasoning to position English as a strategy for competitiveness and local teachers as facilitators/technicians to face this demand. The reduction of bilingualism to "only English" forced a deterministic vision of teachers who started to be judged just for their English proficiency regardless of other dimensions of their teaching; here Appendix B is essential to understanding the rationale behind reform in quest of standardization and homogenization. On the contrary, Appendix C, brings to the surface statements in relation to English, policies and English teachers. Indeed, Table 3 (in Appendix C) allows us to trace contestarian practices to policies in which local English teachers question the rationale of English as a language of prosperity, and also oppose idealized conditions for the implementation of the National Bilingual Plan to real conditions of schools and English teaching and labor in the country. The analysis of the extended archive unveiled some practices of professional development in relation to English teachers' own considerations about their profession and the teaching of the language that can be depicted as struggles of the self to affirm themselves, resist and produce local and relevant knowledge.

After a thorough look at editorials, research articles, reflection articles from university professors, and primary and secondary school teachers from public or private educational institutions, who present themselves as researchers or English teachers or educators, we identified some discursive and non-discursive practices as the key of subjectivity (Appendix C).

\subsection{Becoming Teacher-Researchers}

The value given to the teacher-researcher identity was used to redefine teacher education in undergraduate and postgraduate programs as an element of professional development, essential to generate educational changes. Curricula were irrigated with subjects dedicated to the research of methodologies in language pedagogy and applied linguistics, together with academic writing techniques at a crucial moment (back in the late 90's) in which the dissemination of research and pedagogical implementation results began to take place thanks to the 
emergence of specialized journals. This type of actions was sponsored by different institutions (universities, language centers, associations, among others), led by professors who had completed a master's degree and/or doctoral program in ELT (English Language Teaching) overseas and made contributions in terms of curricular design, educational pillars, integrating scenarios for teacher education and the dissemination of research results and pedagogical reflections.

One of the first journals with circulation in Colombia, currently dedicated to disseminating the knowledge produced in the field of ELT, is HOW journal, a journal of the Colombian Association of Teachers of English. This non-profit association was constituted by the voluntary work of English teachers, who were summoned by the need to generate concrete actions for the improvement of English teaching in Colombia and the professional growth and teachers' qualification in ELT. In the year 1999, in the issue entitled "New Era", the editor of the journal presented as a kind of utopia "the call for innovation and change" to inspire teachers to learn how to ask questions and to be concerned about the problems of teaching and learning English. The preoccupations of the moment were oriented to consolidate "a pedagogy of the foreign language with the capacity to generate innovations in the classroom not only linked to learning but also to broader frameworks of education, didactics and the socio-political aspect" (Gómez, 1996, p 16). Although the concern for the production of local knowledge was not in its initial agenda, later on the association will incorporate dialogues South-North to rescue the English Language Teachers' voices and views about English language teaching.

Subsequently, the journals "Profile" (2000), of the National University and "Colombian Applied Linguistic Journal" (2002) of the Distrital University, both research groups' products in the respective universities, emerged as scenarios in Bogotá for the publication of research results, concentrating their efforts in attracting and promoting action research and innovation in the classrooms (Cárdenas, 2000), as well as the construction of local theories to promote actions and ideological changes (Clavijo, 2003). From this strategy, the role of teacher education was set as a condition of possibility for a teacher capable of generating change. Here, we draw attention to the way in which the editor of Profile journal, in its first issue, conceives the English teacher:

We perceive teachers to be agents of change who are characterized by high self-esteem as well as by cultural and professional identity. Likewise, we suppose teachers possess solid knowledge of their teaching fields and abilities to identify problems as well as to provide solutions to them within particular educational contexts (Cárdenas, 2000 p. 6).

As can be inferred, the consideration of teachers as agents of change is linked to a key assumption, which is the teacher as a subject who possesses knowledge of English teaching and is able to identify and solve problems. However, if the characterization given to the teacher as an agent of change is analyzed in depth, there is no doubt that the conditions of possibility for the emergence of professionals were based on the promotion of high self-esteem, cultural identity, competent handling of the foreign language, as well as feelings of pride for their country and language (Clavijo, 2005). Thus, research, writing and innovation as practices of teacher-researchers constitution were identified also as forms of struggles used by English teachers to become producers of knowledge instead of consumers of it in a period of time in which what was produced in the global North was socially more valued.

As part of the articles writing, we found that teachers rely too much on the knowledge production of ELT from the global North, its theoretical constructs and methodological tools to explain their own reality. The review of citations and bibliographical references of articles shows that citation of foreign authors is greater than the citation of local authors, which is very scarce. This situation subtly begins to change in the articles from the period 2009-2015, where the citation of local authors increased but it does not have the potential to articulate strong lines of thought that could contribute to a general vision of Colombian thought in ELT, except for the line of linguistic policies studies a bit more productive and commented upon, thanks to the emergence of contestarian practices in relation to the National Bilingual Program. In this scenario, becoming an author was a practice subjected to journals' own demands and struggles to be highly categorized. Some of these struggles still persist in terms of difficulties to consolidate human groups to set up editorial and evaluation committees, to attract authors, to obtain financial resources for support, to survive and stand out in the competitive and changing system of measurement between journals.

\subsection{English Teachers as Educators}

The National Bilingual Program (NBP) placed local teachers as a "force" for guaranteeing the success of the program. But this "force" was not ready due to its low English level, thus English teachers needed to be tested, trained, and prepared to follow the experts' recommendations. English teachers' reactions towards this treatment made them realized that the NBP rules of reason placed them as technicians, whose mission was to obey 
uncritically the program without altering the conditions of it. So, teachers confronted this technician identity, embracing the identity of educators which was constructed by teachers' understanding of their mission, practices, experiences and roles in relation to education in a broader sense. A number of different issues were brought into the English teachers' contestarian practices to resist this technician identity and to indicate how the NBP would be thought about and applied.

\subsection{Criticality as a Way of Being}

Local English Teachers' contestarian practices in relation to the notions of the National Bilingual Program (NBP) and its mechanisms for regulating English teaching and assessing teachers (guidelines, standards, textbooks, Common European Framework of References for Languages) allow us to identify how English Teachers positioned themselves from a critical perspective to oppose the idealized English Speaker native-like identity, to scrutinizing the English value declared and to dismantling the bilingualism notion of the program. In doing so, discursive practices of teachers favored social, cultural, linguistic and political domains to unveil the hidden agenda behind the NBP for the commodification and homogenization of English to the detriment of the country's reality and its linguistic richness.

When the NBP was launched a common sense idea started to be also promoted, and that is the idea of local English teachers as supporters and promoters of the program. But it is interesting to note a type of resistance in which criticality takes place and questions assumptions that seem natural or taken for granted. The way English teachers used their knowledge about theory, practice, and social and political conditions for teaching in Colombia to denounce systematic segregation, exclusion and inequities within the program, entails a line of thought in which "being critical" is a condition of the possibility to affirm themselves as the ones most authorized to speak about English teaching and bilingualism in Colombia. It involved the articulation of different resistance practices to contest policies' dominant and must be discourses, using power-knowledge strategies in which other possibilities of being, understanding bilingualism and legitimate English teachers' own experiences and knowledges are included.

One of the aspects English Teachers rejected and questioned was the implementation of standards and the adoption of the Common European Framework (CEF) without an informed perspective of the Colombian reality. For teachers it was incomprehensible to watch the comparison between the European and the Colombian context to copy this approach and use it to promote English (only English) as the language to embark successfully on the path of progress. In this scenario, English Teachers' discourses were very illustrative of the hard and difficult conditions of working in the different zones of the country, the lack of investment and the abandonment of some public schools in the country:

There is a dominant discourse about investing in English, and many people associate it with prosperity, a prosperity that many assume will be available to large sectors of the population. However, the reality is that merely learning English in the context of public education will not guarantee students a better future (Valencia, 2006, p. 7).

What is interesting here is that these discourses were not allegations of a purely laborious nature, but also of a political one in which teachers recognized the effects of dominant discourses, which were based on naturalized truths as effects of marketing and neoliberal discourses that introduced English as the language of business, success, and modernity in order to validate the NBP as the must be program to work on bilingualism, ignoring the linguistic capital of the country:

This is the first hint that for the MEN indigenous languages do not represent any sort of capital, in Bourdieu's terms; henceforth, not worthy of investment, incentives, promotion, [...] English encapsulates and represents the ideal of foreign languages and it is more than enough working on it and ignoring other languages (Vélez-Rendón, 2003, as cited in Guerrero, 2008, p. 31).

A second aspect questioned was the NBP demand of a high English proficiency level for all citizens without acknowledging the particularities of the context, the problems of social and political order, and the needs and priorities of many sectors in Colombia. In their view, the hierarchical structure created by the CEF, instead of generating better possibilities of being and being in schools, promotes new mechanisms to measure, differentiate and deepen the gaps between the rich and poor, public and private sectors, and certified and non-certified teachers (Ayala \& Alvarez, 2005; González, 2009; Usma, 2009).

A last aspect that English teachers problematized was the NBP's deficient view of local English teachers to teach the language. Diagnoses of the NBP were based on test results that indicated English Teachers' low command of English was used to disqualify and disempower local teachers and also to validate teachers' training and English 
courses in order to improve their command of the language. This reductionist consideration of what an English teacher must be, reduced basically to his/her language proficiency, forced teachers to expose the government's absence in sponsoring or supporting English Teachers' participation in professional development programs, grant permission to attend congresses, seminars or university courses, but also to highlight English teachers' commitment to work by themselves, study, travel, design courses (Bastidas \& Muñoz, 2011; Bonilla Carvajal \& Tejada-Sánchez, 2016; Bonilla \& Cruz-Arcila, 2014, among others). Some important practices emerged from this criticality in which resisting must be discourses became a struggle of self-affirmation. Let's see how this works:

\subsubsection{Problematizing the Official Notion of Bilingualism}

Teachers questioned what the National Bilingual Program promoted as bilingualism (Spanish-English), exposing the dominant treatment of English to homogenize and standardize education. These discourses claimed recognition of the multicultural richness in relation to indigenous languages and creoles in the country. Also, English teachers' discursive practices problematized the demand of the NBP to teach English without speaking any Spanish in Colombian classrooms. The preference for Only English invisibilizes the potentiality of Spanish to help students to learn the language and enjoy a linguistic atmosphere closer to students' and teachers' reality. And more importantly, its promotion "creates a false notion that bilingual education is an obstacle to learn the English language" (Macedo, et al., 2003, p. 18). In doing so, a reduced vision of what is understood as bilingualism within the National Plan is dismantled to warn of inequalities and linguistic injustices within the country's communities. In this sense, teachers claim the creation of a bilingualism plan that really considers the linguistic and cultural situation of the Colombian territory to avoid a new form of colonialism. Here, it is important to stress how decolonial studies have impacted doctoral programs in Colombia, (case of the ELT emphasis in the Inter-institutional Doctoral Education Program) in which the ELT community has started to understand colonial situations in relation to subjugation and the invisibility of local beings and knowledges (De Mejía, 2006; Piñeros \& Quintero, 2006; Sánchez \& Obando, 2008; Escobar \& Gómez, 2010; Guerrero, 2009a, 2009b; Torres-Martínez, 2009, and Fandiño, 2013).

\subsubsection{Denouncing the silencing of Teachers' Voice in Public Policy}

The analysis of English teachers' contestarian practices concerning policies unveiled a growing malaise of teachers towards the Ministry of Education's adoption of top-down policies in which English teachers' voices are not heard and teachers are not considered sufficiently reliable to participate in their drafting. Although there are well-known voices in the local ELT community field and proved and reliable knowledge of English teachers, the preference for external institutions or experts from abroad is obviously sponsored by the government. This uneasiness has caused wounds to local English teachers who have been working in English Language teaching and teacher education programs long before the NBP launching. In this sense, they claim their right to govern their own practices, being also policymakers instead of mere acritical teachers who obey government dictates (Cadavid, McNulty, \& Quinchía, 2004; Guerrero, 2009).

\subsubsection{Resisting dominant Practices and Affirming Local Knowledges and Identities}

One of most criticized mechanisms of NBP has been the promotion of a native-like identity with the preference for native English Speakers as a model and the CEF as a measure to rank teachers. This mechanism of differentiation has placed a tremendous strain on teachers' perceptions (Viafara, 2016; Abouchaar, 2012), recruitment practices (Martínez, 2018) and social consideration of local teachers, now labelled as non-natives, without merit to be considered a good English teacher. Indeed, the dichotomy has been effective to promote the business of English teaching in which International Tests are sold as a mechanism to place non-native English teachers' proficiency according to levels that are incorporated in the sense of a No-yet. This no-yet, that can be translated as: I am a $\mathrm{C} 1$ or a $\mathrm{C} 2$, but I am not a native English Teacher is a wound that time ago was not experienced by local teachers with this new emphasis on a racialized identity.

Also, a promising research line in relation to English Teachers' identities concerning power, knowledge, and inequality has emerged as a way to understand professional identities to embrace diversity, difference and affirmation and make visible aspects of gender, race, space, and positioning within different perspectives (See: Méndez \& Clavijo, 2017; Castañeda-Peña, 2008; Castañeda-Peña \& Ubaqué, 2017; Guerrero, \& Quintero, 2013, among others).

\section{Discussion}

The following figure illustrates the relation of forces affecting English language teachers' construction of their subjectivities. This device works as a polyhedron of intelligibility (Leonard \& Foucault, 1982, p. 62) because it 
allows us to register several facets of an event in light of the analysis of the archive. It is worth clarifying that the archive dispersed in time and subjected to random other forces that intersect (social, economic, political, educational) does not obey a linear order or presupposed regularities but, on the contrary, what it allows us to observe is how certain practices are juxtaposed, overlapped, contradicted and even supported by discursive practices coming from different sources of expertise.

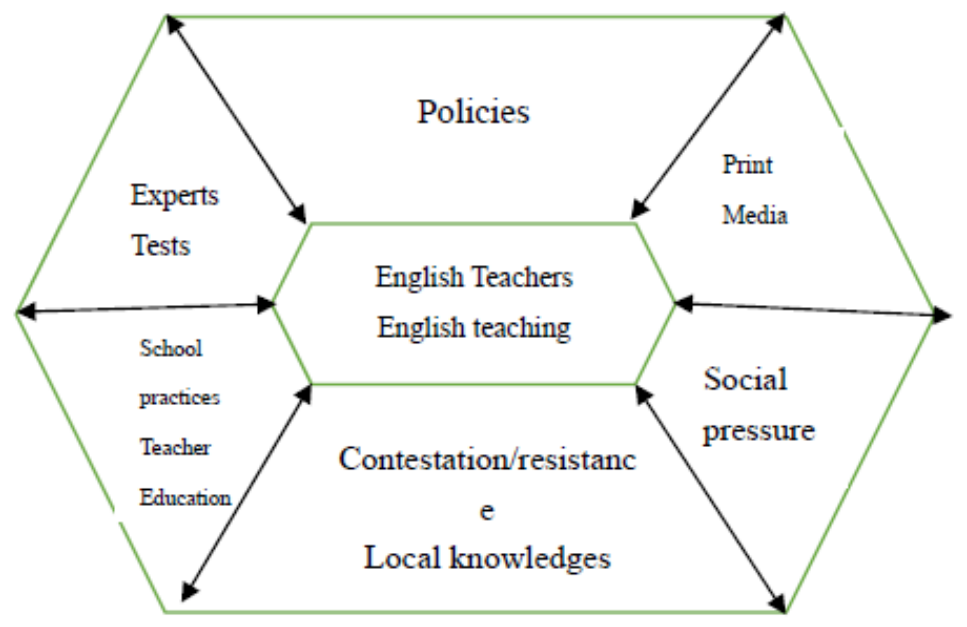

Figure 1. Polyhedron of intelligibility among forces affecting

This figure is important to highlight how the production of English teachers' identity, as an object in the law created to discipline, regulate and produce a normalized identity, affects and is affected by others forces in which the production of a response -via resistance practices- made visible the capacity of subjectivity on the part of teachers. Our focus on the "production of English teachers" within the NBP as a political practice led us to trace discursive formations that this program carried as must-be discourses to construct an idealized English teacher identity, a notion of bilingualism, a bilingual citizen and also English teaching practices that function to enclose and subject. First, we realized through the historical revision of registers that some years before the launch of the NBP, local English teachers were not assaulted by discrediting generalizations and mechanisms of control and discipline (Foucault, 1977). Indeed, they enjoyed a certain extent of recognition and prestige. Once the promotion of the NBP had been in place, its technologies of power-knowledge altered the way English teachers were perceived.

Seduced by Foucault's discussion of the double-sided character of subjection/subjectification in relation to practices of a self-governance mentality, the analysis of registers from English Teachers' discursive and non-discursive practices allowed us to trace some practices of self-affirmation, work of the self in which the apparatus of subjectivity is experienced and also, to revise contestarian practices in which resistance as a power exercise practice served to problematize the NBP, question it, denounce its mechanisms of exclusion, inequity and normalization of some practices and identities. Among these discursive and non-discursive practices, becoming teacher-researchers, authors, being critical and positioning themselves as educators recharged a low status image with positive value works against domination and offered alternative ways of being and working to envision more empowering subjectivities for English teachers.

What this work brought to the surface is teachers' struggles to govern their own existence and work. We do not mean to romanticize these struggles or to suggest that all English teachers are resistors of dominant and must-be discourses. Indeed, we venture to say that some of them enjoyed the mechanisms of control created by the system or think of themselves as ambassadors of English global north, replicating and perpetuating these must-be discourses. What we would like to pinpoint is that the archive constructed in this research subverts the normalized subjection of the NBP and provides a niche to analyze the complexities of English teachers'subjectivities to embrace identity positions, knowledges, actions, but also their contradictions, wounds, fears and resentments. This journey is merely a beginning and an open door to continue exploring subjectivity as a site for resistance. 


\section{Acknowledgments}

This research and paper are possible due to the financial support of the Center for Research and Scientific Development (CIDC in its Spanish acronym) of Distrital University. Authors express their gratitude to Francisco Martínez and German Osorio for their contribution in constructing the archive, and also to Francisco Pérez-Gómez for reviewing the manuscript and Randall Davis Barfield for his professional services as proofreader.

\section{References}

Abouchaar, A. (2012). Contra el hablante/oyente ideal y la ideología del monolingüismo [Against the ideal speaker-listener and the ideology of monolingualism]. Forma y Función, 25(2), 85-97.

American Psychological Association. (1972). Ethical standards of psychologists. Washington, DC: American Psychological Association.

Atkins, K. (2005). Self and Subjectivity. Oxford: Blackwell Publishing. https://doi.org/10.1002/9780470774847

Ayala Zárate, J., \& Álvarez V., J. (2005). A Perspective of the Implications of the Common European Framework Implementation in the Colombian Socio-cultural Context. Colombian Applied Linguistics Journal, 0(7), 7-26. https://doi.org/10.14483/22487085.162

Bastidas, J., \& Muñoz Ibarra, G. (2011). A Diagnosis of English Language Teaching in Public Elementary Schools in Pasto, Colombia. HOW Journal, 18(1), 95-111.

Biehl, J., Good, B. \& Kleinman, A. (2007). Subjectivity. California: University of California Press.

Bonilla Carvajal, C., \& Tejada-Sanchez, I. (2016). Unanswered Questions in Colombia's Foreign Language Education Policy. Profile: Issues in Teachers' Professional Development, 18(1), 185-201. https://doi.org/10.15446/profile.v18n1.51996

Cadavid Múnera, I., McNulty, M., \& Quinchía Ortiz, D. (2004). Elementary English Language Instruction: Colombian Teachers' Classroom Practices. Profile: Issues in Teachers' Professional Development, 5(1), 37-55.

Cárdenas, M. L. (2000). Editorial. PROFILE Issues in Teachers' Professional Development, 1(1), 6-7.

Castañeda Peña, Harold Andrés. (2008). 'I said it!' 'I'm first!': Gender and language-learner identities. Colombian Applied Linguistics Journal, (10), 112-125.

Castañeda-Peña, H., \& Ubaqué, D. (2017). Teacher Research: Uncovering Professional Identities and Trajectories of Teacher Researchers through Narrative Research-A Colombian Case. International Education Studies, 10(3), 35-45. https://doi.org/10.5539/ies.v10n3p35

Cheung Ling, Y. (2015). Teacher Identity in ELT/TESOL: A Research Review. In Y. L. Cheung, B. S. Said, \& K. Park (Eds.). Advances and Current Trends in Language Teacher Identity Research (pp. 16-30). New York: Routledge.

Correa, D., \& Usma Wilches, J. (2013). From a Bureaucratic to a Critical-Sociocultural Model of Policymaking in Colombia. HOW Journal, 20(1), 226-242.

Clavijo, A. (2003). Editorial. Colombian Applied Linguistics Journal, 1(5), 1-2.

Clavijo, A. (2005). Editorial. Colombian Applied Linguistics Journal, 7, 5-6.

Cruz Arcila, F. (2007). Broadening Minds: Exploring Intercultural Understanding in Adult EFL Learners. Colombian Applied Linguistics Journal, O(9), 144-173. https://doi.org/10.14483/22487085.3149

De Mejía, Anne-Marie. (2006). Bilingual Education in Colombia: Towards a Recognition of Languages, Cultures and Identities. Colombian Applied Linguistics Journal, 8, 152-168. https://doi.org/10.14483/22487085.176

Escobar Alméciga, W., \& Gómez Lobatón, J. (2010). Silenced Fighters: Identity, Language and Thought of the Nasa People in Bilingual Contexts of Colombia. Profile: Issues in Teachers' Professional Development, 12(1), 125-140.

Fandiño, Y. (2013). Knowledge base and EFL teacher education programs: A Colombian perspective. Íkala, revista de lenguaje y cultura, 18(1), 83-95.

Foucault, M. (1972). The Archaeology of Knowledge and The Discourse on Language. Pantheon Books, New York.

Foucault, M. (1977) [1975]: Discipline and Punish. The Birth of the Prison. New York: Vintage Books. 
Foucault M. (1988). Technologies of the Self. In L. H. Martin, H. Gutman, \& P. H. Hutton. (Eds.). A Seminar with Michel Foucault. Great Britain: Tavistock Publications

Foucault, M. (2011). The Courage of the Truth (The Government of Self and Others II). Lectures at The Collège De France 1983-1984. UK: Palgrave Macmillan

Foucault, M. (1981). "Subjectivité et Vérité", Annuaire du Collège de France, núm. 81, "Histoire des Systèmes de Pensé", Colegio de Francia, París, pp. 385-389.

Foucault, M. (1982) The Subject and Power. Critical Inquiry, 8, 777-795. https://doi.org/10.1086/448181

Fullan, M., \& Hargreaves, A. (2013). Teacher development and educational change (2nd ed.), London: Routledge.

Gómez, L. (2016). The Utopia of Innovation and Change in Colombia: A Dipstick Speech for an EFL Teacher Growth Conference. HOW Journal, 1(1), 10-16.

Gómez, S., \& Mary, M. (2017). Review and Analysis of the Colombian Foreign Language Bilingualism Policies and Plans. How, 24(1), 139-156. https://doi.org/10.19183/how.24.1.343

González, A. (2007). Professional development of EFL teachers in Colombia: Between colonial and local practices. Íkala, revista de lenguaje y cultura, 12(18), 309-332.

González, A. (2009). On alternative and additional certifications in English language teaching: The case of Colombian EFL teachers' professional development. Íkala, revista de lenguaje y cultura, 14(22), 183-209.

González Moncada, A., \& Sierra Ospina, N. (2005). The Professional Development of Foreign Language Teacher Educators: Another Challenge for Professional Communities. Íkala, revista de lenguaje y cultura, 10(16), 11-39.

Guattari, P. F. (1996). The Guattari Reader. Oxford: Blackwell Publishers Ltd.

Guerrero, C. (2009). Language Policies in Colombia: The Inherited Disdain for our Native Languages. HOW Journal, 16(1), 11-24.

Guerrero, C. H. (2009). The portrayal of EFL teachers in official discourse: The perpetuation of disdain. PROFILE Issues in Teachers' Professional Development, 12(2), 33-49.

Guerrero, C. (2010). The Portrayal of EFL Teachers in Official Discourse: The Perpetuation of Disdain. Profile: Issues in Teachers'Professional Development, 12(2), 33-49.

Guerrero, C., \& Meadows, B. (2015). Global Professional Identity in Deterretorialized Spaces: A Case Study of a Critical Dialogue Between Expert and Novice Nonnative English Speaker Teachers. Profile: Issues in Teachers' Professional Development, 17(2), 13-27 https://doi.org/10.15446/profile.v17n2.44194

Guerrero, C. H., \& Quintero, A. (2016). Las voces de los maestros frente a las políticas educativas: ¿la ilusión de la democracia? Universidad Distrital Francisco José de Caldas.

Helena Guerrero, C. (2008). Bilingual Colombia: What does It Mean to Be Bilingual within the Framework of the National Plan of Bilingualism? Profile: Issues in Teachers' Professional Development, 10(1), 27-45.

Kleinman \& Fitz-Henry, (2007). The Experiential Basis of Subjectivity: How individuals Change in The Context of Societal Transformation. In J. Biehl, B. Good, \&A. Kleinman (Eds.), Subjectivity. California: University of California Press (pp. 52-65).

Lazarrato. (2014). Signs and machines. Capitalism and the Production of Subjectivity. United States: Semiotext.

Macedo, D., Dendrinos, B., \& Gounari, P. (2003). The Hegemony of English. Boulder, CO: Paradigm.

Marx, S., \& Martínez, Y. (2018). The Native Speaker Fallacy in English Teachers' Recruitment Practices: voices of resistance within a social network. Universidad Distrital Francisco José de Caldas. Unpublished Thesis.

Méndez, P., \& Clavijo-Olarte, A. (2017). Teachers' identities under the magnifying glass in the EFL field: Crossing intellectual borders. Colombian Applied Linguistics Journal, 19(1), 7-10. https://doi.org/10.1448 3/calj.v19n1.11600

Mendieta, A., \& Jenny, A. (2009). Inquiry as an opportunity to make things differently in the language classroom. Colombian Applied Linguistics Journal, (11), 124-135.

Pennington, M. C. (2015). Teacher Identity in TESOL: A Frames Perspective. In Y. L. Cheung, S. B. Said, \& K. Park (Eds.). Advances and Current Trends in Language Teacher Identity Research (pp. 16-30). New York: Routledge. 
Piñeros Pedraza, C., \& Quintero Polo, Á. (2006). Conceptualizing as Regards Educational Change and Pedagogical Knowledge: How Novice Teacher-Researchers' Proposals Illustrate this Relationship. Profile: Issues in Teachers' Professional Development, 7(1), 173-186.

Quintero Polo, Á., \& Guerrero Nieto, C. (2013). "Of Being and not Being:” Colombian Public Elementary School Teachers' Oscillating Identities. HOW Journal, 20(1), 190-205.

Sánchez Solarte, A., \& Obando Guerrero, G. (2008). Is Colombia Ready for "Bilingualism"? Profile: Issues in Teachers' Professional Development, 9(1), 181-195.

Stanulis, R., Cooper, K., Dear, B., Johnston, A., \& Richard-Todd, R. (2016). Teacher-led reforms have a big advantage - Teachers. The Phi Delta Kappan, 97(7), 53-57. https://doi.org/10.1177/0031721716641650

Terhart, Ewald. (2013). Teacher resistance against school reform: Reflecting an inconvenient truth. School Leadership and Management, 33. https://doi.org/10.1080/13632434.2013.793494

Usma Wilches, J. (2009). Education and Language Policy in Colombia: Exploring Processes of Inclusion, Exclusion, and Stratification in Times of Global Reform. Profile: Issues in Teachers' Professional Development, 11(1), 123-141.

Valencia Giraldo, S. (2006). Literacy practices, texts, and talk around texts: English language teaching developments in colombia. Colombian Applied Linguistics Journal, O(8), 7-37. https://doi.org/10.1448 $3 / 22487085.170$

Vélez-Rendón, G. (2003). English in Colombia: A sociolinguistic profile. World Englishes, 22(2), 185-198. https://doi.org/10.1111/1467-971X.00287

Viafara, J. (2016). "I'm Missing Something": (Non) Nativeness in Prospective Teachers as Spanish and English Speakers. Colombian Applied Linguistics Journal, 18(2), 11-24. https://doi.org/10.14483/calj.v18n2.9477

Ximena Bonilla, Sandra, \& Cruz-Arcila, Ferney. (2014). Critical Socio-Cultural Elements of the Intercultural Endeavour of English Teaching in Colombian Rural Areas. Profile Issues in Teachers` Professional Development, 16(2), 117-133. https://doi.org/10.15446/profile.v16n2.40423

\section{Note}

Note 1. It is important to highlight that these tables in appendixes were constructed taking some excerpts from archives, whose size and structure made impossible a direct translation.

\section{Copyrights}

Copyright for this article is retained by the author(s), with first publication rights granted to the journal.

This is an open-access article distributed under the terms and conditions of the Creative Commons Attribution license (http://creativecommons.org/licenses/by/4.0/). 